\title{
Efficacy of recycled sand or organic solids as bedding sources for lactating cows housed in freestalls
}

\author{
N. M. Esser, ${ }^{1}$ H. Su, ${ }^{2}$ W. K. Coblentz, ${ }^{3 *}$ M. S. Akins, ${ }^{4}$ B. A. Kieke, ${ }^{5}$ N. P. Martin, ${ }^{6}$ M. A. Borchardt, ${ }^{3}$ \\ and W. E. Jokela ${ }^{7}$ \\ ${ }^{1}$ University of Wisconsin Marshfield Agricultural Research Station, Marshfield 54449 \\ ${ }^{2}$ Department of Animal Nutrition and Feed Science, China Agricultural University, Beijing 100193 \\ ${ }^{3}$ USDA-Agricultural Research Service, US Dairy Forage Research Center, Marshfield, WI 54449 \\ ${ }^{4}$ Department of Dairy Science, University of Wisconsin, Madison 53706 \\ ${ }^{5}$ Marshfield Clinic Research Institute, Marshfield, WI 54449 \\ ${ }^{6}$ USDA-Agricultural Research Service (retired), US Dairy Forage Research Center, Madison, WI 53706 \\ ${ }^{7}$ USDA-Agricultural Research Service (retired), US Dairy Forage Research Center, Marshfield, WI 54449
}

\section{ABSTRACT}

Our objective was to compare the composition of bedding materials and manure, cow welfare and hygiene assessments, measures of milk production and quality, and incidence of mastitis during a $3-\mathrm{yr}$ trial with lactating Holstein cows housed in a freestall barn containing 4 identical pens with 32 freestalls/pen. Bedding systems evaluated included deep-bedded organic manure solids (DBOS), shallow-bedded manure solids spread over mattresses (MAT), deep-bedded recycled sand (RSA), and deep-bedded new sand (NSA). The experiment was designed as a $4 \times 4$ Latin square with 4 bedding systems and 4 experimental periods, but was terminated after $3 \mathrm{yr}$ following discussions with the consulting statistician; therefore, data were analyzed as an incomplete Latin square. A total of $n=734$ mostly primiparous cows ( $\mathrm{n}=725$ primiparous, $\mathrm{n}=9$ multiparous; 224 to 267 cows/yr) were enrolled in the trial. Before placement in freestalls, organic solids (OS) exhibited lower concentrations of dry matter (36.5 vs. $94.3 \%$ ), and greater concentrations of volatile solids, C, $\mathrm{N}, \mathrm{NH}_{4}-\mathrm{N}, \mathrm{P}$, water-extractable $\mathrm{P}, \mathrm{K}$, and $\mathrm{S}$ compared with RSA or NSA. Cow comfort index was greater for sand-bedded systems compared with those using OS (88.4 vs. $82.8 \%$ ). Cows bedded in systems using OS (DBOS and MAT) exhibited greater mean hock scores ( 1 = no swelling, no hair loss; $2=$ no swelling, bald area on hock) than those bedded in sand (1.25 vs. 1.04), but this effect was entirely associated with use of mattresses (MAT), which differed sharply from DBOS (1.42 vs. 1.07). Generally, hygiene scores for legs, flanks, and udders were numerically similar for DBOS, NSA, and

Received October 15, 2018.

Accepted March 28, 2019.

*Corresponding author: wayne.coblentz@ars.usda.gov
RSA bedding systems, and differences between bedding systems were associated entirely with MAT, yielding detectable contrasts between MAT and DBOS for legs (2.94 vs. 2.20$)$, flanks (2.34 vs. 1.68), and udders (1.83 vs. 1.38). No significant contrast comparing bedding systems was detected for measures of milk production or quality. Documented cases of clinical mastitis requiring treatment ranged from a low rate of 7.4 cases/yr for RSA to a high of 23.1 cases/yr for DBOS, based on a mean enrollment of 60.7 to 63.0 cows/treatment per yr. Cows bedded with OS exhibited a greater incidence of mastitis than those bedded with sand (19.0 vs. 8.4 cases/yr), but no differences were observed for comparisons within individual bedding-material types. Collectively, these results generally favored use of sandbedding materials over systems using OS.

Key words: bedding, freestall, organic solid, recycled sand

\section{INTRODUCTION}

Currently, multiple choices exist for the resting surface and bedding type for dairy herds housed in freestalls. These management choices are based on a variety of factors that include manure-handling requirements/ logistics, cost of purchased bedding materials, and a variety of cow health, comfort, and well-being considerations. A recent survey (Brotzman et al., 2015) of ( $\mathrm{n}=$ 201) large Upper Midwest dairies ranging in size from 203 to 8,064 cows (mean $=650 \pm 770$ cows) reported that $68.2 \%$ of the dairies used some form of deep-bedded resting surface, with the balance $(31.8 \%)$ utilizing a rubber surface. The same study also reported that the preferred bedding material was sand $(66.2 \%)$, with other dairies using wood shavings or sawdust (16.4\%), straw/hulls/husks (11.0\%), or manure solids (4.5\%). Several studies have suggested that sand is an ideal 
bedding, and will reduce (1) time standing in freestalls (Cook et al., 2005); (2) lameness and incidence of standing in stalls compared with mat or mattress surfaces (Cook et al., 2004); (3) bulk milk SCS (Rowbotham and Ruegg, 2015); (4) incidence of hock lesions and severe hock lesions (Adams et al., 2017); and (5) counts of coliforms and Klebsiella bacteria in bedding and on teat ends (Zdanowicz et al., 2004). In a review, Bewley et al. (2017) summarized 5 primarily physical, but practical, qualities of sand that contribute to its wide acceptance as the bedding of choice in most freestallhousing systems. These include (1) a more comfortable resting surface, (2) limiting effect on bacterial growth, (3) low initial moisture concentration, (4) a surface that remains cool, thereby reducing heat stress, and (5) reduced cow slippage in alleys via improved traction. A recent corroborative survey of high-producing ( $\mathrm{n}=$ 325) dairy herds in Wisconsin (Rowbotham and Ruegg, 2015) concluded that large Wisconsin dairy farms using inorganic (primarily sand) bedding exhibited greater productivity and better milk quality than herds using other bedding types. Although these benefits of sand bedding are compelling arguments for its use, there are some disadvantages that must be considered in any management decision. Although purchase costs for sand are an obvious negative input, producers frequently express even greater concerns about the costs of manure-handling equipment, sand separation from manure, and repairs to equipment that are often exacerbated by the abrasive nature of sand. As such, the animal-welfare benefits of sand bedding are constantly weighed against the costs and complications of managing sand-laden dairy manure.

As mentioned previously, other forms of (mostly) organic bedding materials have been used successfully in freestall operations, both to top-dress mattresses and within deep-bedded stalls (Bewley et al., 2017). Generally, recovered organic manure solids (OS) are attractive for this purpose because they do not need to be purchased and are available in near limitless supply. However, organic bedding materials, such as green sawdust, have long been associated with greater counts of Klebsiella spp.; for this reason, sources of sawdust for freestall bedding are usually kiln-dried before use, ostensibly to kill most bacteria (Bewley et al., 2017). However, mastitic infection may be multifactorial in nature, and large populations of coliform organisms are not always linked directly to increased mastitic infection, particularly if housing conditions and milking procedures are well managed (Fairchild et al., 1982). Regardless, producer anxieties concerning wet organic bedding sources persist, and recently published extension materials continue to recommend against the use of green sawdust bedding (Looper, 2012).
Much like green sawdust, OS recovered from manure separation systems often raise similar concerns, in part because of their relatively high moisture content; in a survey of 38 Midwest dairy operations, mean moisture concentrations of digested, composted, and raw manure solids were $72.9,60.3$, and $72.6 \%$, respectively (Husfeldt et al., 2012). In addition, some studies have demonstrated high counts of gram-negative bacteria, coliforms, and Klebsiella spp. Cole and Hogan (2016) reported that fresh recycled manure solids exhibited gram-negative bacterial counts that were about $0.5 \log _{10} \mathrm{cfu} / \mathrm{g}$ of DM greater than those from composted manure solids at the time they were placed in the freestalls; similarly, counts for coliforms, as well as Klebsiella and Streptococcus species, were about $1.0 \log _{10} \mathrm{cfu} / \mathrm{g}$ of DM greater in the fresh bedding. However, these differences were retained only for gram-negative bacteria $1 \mathrm{~d}$ later, and by d 2, no differences were present between bedding sources for any of the infectious organisms. Husfeldt et al. (2012) found that drum-composting recycled OS eliminated coliform bacteria, but this advantage did not persist after composted solids were placed in freestall housing. As discussed for green sawdust, direct linkages with the incidence of clinical mastitis have been somewhat difficult to establish; Rowbotham and Ruegg (2016a) did not detect differences in incidence of clinical mastitis between deep-bedded OS, shallow-bedded OS (over mattresses), recycled sand, and new sand, although cases for cows bedded in new sand were numerically less. Similarly, Husfeldt et al. (2012) concluded that SCC for cows in the Upper Midwest bedded with organic solids were comparable to the norm throughout the region and were not excessively high, although this may contrast sharply with the negative perception still held by many dairy producers.

Other management issues concerning use of recycled manure products include those related to elevated counts of gram-negative bacteria, coliforms, Klebsiella spp., or Streptococcus organisms in recycled sand bedding compared with new sand (Rowbotham and Ruegg, 2016b), and propane flaming has been considered to reduce elevated counts within freestalls bedded with recycled sand (Hogan et al., 2012). Perhaps more importantly, the decision whether to deep-bed or apply a shallow layer over another surface (usually rubber mattresses) has implications with respect to both bacterial counts and animal welfare. Several studies have associated deep-bedded freestalls, mostly bedded with new sand, with reduced incidence of lameness (Cook et al., 2005, 2016; Chapinal et al., 2013; Adams et al., 2017), hock and knee injuries (Cook et al., 2016), decreased standing time within stalls (Cook et al., 2005), and a greater proportion of cows touching a freestall that were lying down (Cook et al., 2004). Most surveys 
assessing these animal welfare issues have emphasized favorable comparisons of deep-bedded sand against a variety of bedding materials spread in thin layers over mattresses, and some (van Gastelen et al., 2011) suggest deep-bedded litter materials also represent a more comfortable resting surface than mattresses. Ideally, management strategies that avoid the additional costs of purchasing sand, as well as the subsequent management of sand-laden manure, but retain the advantages of deep-bedding for cow comfort and welfare, would be highly desirable for dairy producers. Furthermore, the opportunity to evaluate bedding systems solely within a single barn at the University of Wisconsin Marshfield Agricultural Research Station that is operated under consistent and highly controlled management, and with near exclusively primiparous cows, contrasts sharply from the more common survey-type studies with varying management styles and systems, as well as high percentages of multiparous cows. Our objectives for this 3 -yr study were to evaluate the composition of bedding materials and manure, as well as the production, health, hygiene, and milk quality of primarily primiparous cows housed in a common freestall barn bedded with deep-bedded OS (DBOS), shallow-bedded OS spread over mattresses (MAT), recycled sand (RSA), or new sand (NSA), where the OS and RSA were reclaimed as by-products of the manure separation system.

\section{MATERIALS AND METHODS}

\section{Cows}

Enrollment. All standards of animal care used in this research trial were approved by the Research Animal Resources Committee of the University of WisconsinMadison (protocol \#A005037). Data reported herein were collected during a 3-yr period from January 2014 through December 2016 at the University of Wisconsin Marshfield Agricultural Research Station, located near Stratford, Wisconsin. All cows enrolled in the trial were part of the University of Wisconsin Integrated Dairy; as such, they generally calved at Marshfield, entered the study as primiparous Holstein cows, and were enrolled in the trial during their first lactation only. A total of $\mathrm{n}=9$ multiparous cows $(\mathrm{n}=6,1$, and 2 of parity 2 , 4 , and 5, respectively) were included initially (2014) to fully populate the experiment, but all other cows enrolled during 2014, 2015, and 2016 were primiparous $(\mathrm{n}=734)$. After parturition, primiparous cows were assigned randomly to 1 of the 4 research pens, such that individual pen populations were maintained equally, and at near capacity $(\mathrm{n}=32$ cows). Because multiparous cows represented only about $1 \%$ of the
Table 1. Numbers of enrolled cows that were housed in freestalls with 4 bedding systems by treatment and year at the University of Wisconsin Marshfield Agricultural Research Station, Stratford

\begin{tabular}{lccccc}
\hline & \multicolumn{5}{c}{ Bedding system $^{1}$} \\
\cline { 2 - 4 } Year & DBOS & MAT & NSA & RSA & Total \\
\hline 2014 & 57 & 56 & 57 & 54 & 224 \\
2015 & 64 & 65 & 60 & 63 & 252 \\
2016 & 64 & 68 & 70 & 65 & 267 \\
Total & 185 & 189 & 187 & 182 & 743 \\
\hline
\end{tabular}

${ }^{1}$ Bedding system: DBOS $=$ deep-bedded organic solids; MAT $=$ organic solids spread over foam-core mattresses; NSA = deep-bedded new sand; and RSA = deep-bedded recycled sand recovered from the screw-type sand separator.

total trial enrollment, parity was not considered in any subsequent analysis of data. Typically, dry cows do not remain at Marshfield; therefore, at the end of their first lactation, cows were transported to the University of Wisconsin Blaine Dairy Research Center (Arlington, WI), where they were assigned to other studies during subsequent lactations, or culled. Total annual enrollment ranged from 224 to 267 cows/yr, with a total of 743 cows enrolled for the 3 -yr trial (Table 1 ).

Diet. During the 3-yr trial, cows were offered a TMR diet formulated with 49.5 to $54.3 \%$ forage, and composed of primarily corn silage and alfalfa haylage; other small percentages of alfalfa hay, alfalfa baled silage, oatlage, oatlage with peas, sorghum silage, and wheat straw were included periodically within the TMR, ranging from 0.5 to $6.1 \%$ of dietary DM calculated on an annual basis. High-moisture corn accounted for 21.4 and $17.2 \%$ of dietary DM during 2014 and 2015, but a much reduced percentage $(5.4 \pm 7.22 \%)$ during the final year of the trial. Diets were formulated weekly based on the analysis of component forages and concentrates submitted to the University of Wisconsin Soil and Forage Laboratory (Marshfield, WI); nutrient analyses were conducted by near-infrared reflectance spectroscopy, and energy calculations were based on the summative approach per NRC (2001) specifications. Overall, the mean annual nutrient composition (as formulated) ranged narrowly: (1) DM, 48.6 to $51.8 \%$; (2) CP, 17.2 to $17.4 \%$; (3) NDF, 28.1 to $28.6 \%$; (4) NFC, 41.5 to $45.4 \%$; and (5) $\mathrm{NE}_{\mathrm{L}}$, 1.65 to $1.74 \mathrm{Mcal} / \mathrm{kg}$ of DM. The TMR was offered twice daily in equal portions at 0500 and $1100 \mathrm{~h}$, and feed was pushed back within easy reach of the cows approximately every $2 \mathrm{~h}$ between 0800 and $1800 \mathrm{~h}$.

\section{Facilities}

Barn. The $29.3 \times 59.4-\mathrm{m}$ lactating-cow barn contained 128 freestalls that were divided equally into 4 independent pens that were designed identically, each 
consisting of 32 freestalls. Two of the 4 pens in the barn were positioned on each side of a drive-through feed alley, and a drover's alley located perpendicular to the feed alley further subdivided each half of the barn to create 4 equal pens. Each pen contained 2 rows of 16 freestalls, arranged in a head-to-head configuration, with a crossover alley fitted with rubber-matted floor coverings on each end of the pen. Adjacent to each crossover alley was a trough-type automatic waterer, such that each pen had 2 sources of fresh water. In addition, a permanently mounted automatic rotating grooming brush (Lely Industries, Maassluis, the Netherlands) was positioned on one end of each pen.

Within each pen, the distance from the back curb of the freestalls to the head-locking feeding gates was 4.06 $\mathrm{m}$; of that distance, the $1.52 \mathrm{~m}$ closest to the feed alley was fitted with rubber floor mats, such that cows did not stand directly on concrete while eating. The alley located furthest from the feed alley and adjacent to the outside wall of the building (resting alley) was narrower $(2.49 \mathrm{~m})$; both alleys were scraped 3 times daily with a skid-steer loader equipped with a rubber blade, which occurred during both milkings, when cows were not present in the barn, and at approximately $1200 \mathrm{~h}$ daily. Alleys were scraped only twice daily during winter months ( $\sim 90 \mathrm{~d} /$ yr; December through February) when they contained frozen manure; during this time period, a skid-steer loader equipped with a metal bucket was used to clean the alleys.

Freestalls and Bedding. Freestalls were $1.28 \mathrm{~m}$ wide and $1.65 \mathrm{~m}$ from the rear curb to the brisket locator. Furthermore, freestalls were configured such that they measured a distance of $1.78 \mathrm{~m}$ along a horizontal plane from the neck rail to a point vertically above the rear edge of the curb; in addition, the curb height was $0.23 \mathrm{~m}$, as measured from the alley surface. For each experimental period lasting approximately 1 yr $(\sim 50$ wk), pens within the barn were assigned to a specific bedding treatment. Generally, each period began about January 1 and was terminated in early to mid December, thereby allowing approximately $3 \mathrm{wk}$ to change bedding materials in each pen by a randomized assignment schedule determined before the study was initiated. Bedding treatments included (1) NSA; (2) RSA that was recovered from dairy manure by a screw-type sand separator (McLanahan Corp., Holidaysburg, PA); (3) DBOS recovered from dairy manure with a screenpress system (model PSS1.2-520, FAN Separator Gesellschaft, Marktschorgast, Germany); and (4) MAT, where OS was recovered as described previously, but then spread in a thin layer over foam-core mattresses (North Brook Farms Inc., Auburn, NY). Cows remained in their original pen grouping throughout their first lactation, and pen groups did not change locations within the barn. Therefore, during winter months some cows within a given pen group overlapped the late-December change of bedding systems; as such, approximately $45 \%$ of all enrolled cows contributed data to 2 treatments. In these cases, cows had to be in residence on a given freestall bedding system for $30 \mathrm{~d}$ in order for their data to be included in calculation of experimental means and the associated statistical analyses.

Before placing bedding materials in the freestalls, recycled beddings (RSA and OS) were managed with consistent preparatory protocols. Recycled sand recovered from the sand separator was placed in piles on a concrete surface and allowed to weather and drain for approximately $3 \mathrm{wk}$ before use in the freestalls. The OS were removed from the solids press, and then placed in a thin layer $(\sim 0.3 \mathrm{~m}$ deep $)$ within a concrete bunker, where they were mechanically stirred daily and air dried with large electric fans for 3 to $4 \mathrm{~d}$ before placement in freestalls. The concrete bunker containing OS was located in an enclosed building that was heated during winter months. The type of mattresses used in this study did not require permanent attachment, which allowed them to be rotated to a different pen within the barn in accordance with the pre-planned rotation schedule. The base of all deep-bedded stalls (NSA, RSA, and DBOS) was $20 \mathrm{~cm}$ of compacted limestone, on which was added approximately $30 \mathrm{~cm}$ of each respective (deep) bedding material. All freestalls were groomed and leveled twice daily, and they were refreshed with new bedding twice weekly. In addition, deep-bedded stalls were mechanically groomed 3 times/wk with a grooming attachment (Appleton Steel, Appleton, WI) affixed to a skid steer loader. For MAT, 1.5 to $3.0 \mathrm{~cm}$ of OS was added to the rear of each stall every time bedding was refreshed $(2 \times$ weekly), with additional OS placed in front of the brisket board to serve as a reservoir for daily grooming to the same standard until the next scheduled refreshing.

\section{Manure and Bedding Sampling and Analysis}

Each bedding material (NSA, RSA, and OS) was sampled monthly, immediately before distribution into the freestalls. Bedding samples were placed in sealed freezer bags and then maintained at $-20^{\circ} \mathrm{C}$ pending subsequent analysis. Manure characteristics were assessed by monthly sampling of manure from each of the 2 alleys (feed and resting) within each pen. Manure from each alley was scraped onto a concrete pad; thoroughly mixed with a skid-steer loader equipped with a bucket attachment; further mixed by hand using rakes, shovels, or both; and then rigorously grab-sampled from various points in the pile. Grab samples for each pen were composited within a large plastic tub; after further thorough mixing, 1-L subsamples were placed in plastic 
sample bottles and stored at $-20^{\circ} \mathrm{C}$. Immediately before analysis, manure samples were defrosted at room temperature for about $48 \mathrm{~h}$. The $\mathrm{pH}$ of manure was determined at room temperature from $25-\mathrm{mL}$ samples using a portable bench-top pH meter (Orion Star A211, Thermo Fisher Scientific Inc., Beverly, MA); the pH of bedding materials was determined similarly following dilution of $20-\mathrm{cm}^{3}$ samples with $40 \mathrm{~mL}$ of distilled water $(2: 1 ; \mathrm{vol} / \mathrm{vol})$, vigorous stirring, and equilibration for $0.5 \mathrm{~h}$ at room temperature before reading the $\mathrm{pH}$ (Peters et al., 2003). Densities of manure and bedding materials were determined on an as-is basis by filling a tared beaker to the 30-mL mark with manure, OS, NSA, or RSA while gently tapping to encourage settling; the weight $(\mathrm{g})$ of beaker contents was then divided by 30 $\mathrm{cm}^{3}$ to yield an as-is density $\left(\mathrm{g} / \mathrm{cm}^{3}\right)$.

Analysis of both bedding and manure included determinations of DM, total $\mathrm{N}, \mathrm{P}, \mathrm{K}, \mathrm{S}$, total $\mathrm{C}, \mathrm{NH}_{4}-\mathrm{N}$, water-extractable P (WEP), and volatile solids (VS). Analyses of P, K, S, $\mathrm{NH}_{4}-\mathrm{N}$ (Peters et al., 2003), and WEP (Kleinman et al., 2007) were conducted by the University of Wisconsin Soil and Forage Laboratory. Moisture concentrations were determined by drying overnight under forced air at $105^{\circ} \mathrm{C}$; subsequently, VS was determined by measuring the percentage of DM lost on ignition in a muffle furnace at $500^{\circ} \mathrm{C}$ for $2 \mathrm{~h}$. Total $\mathrm{N}$ was determined by combustion methodology (AOAC, 1998, Official Method 990.03; Elementar Americas Inc., Mt. Laurel, NJ), with $\mathrm{C}$ determined simultaneously from the same sample and instrument. A ratio of $\mathrm{C}$ to $\mathrm{N}$ was then calculated from these inputs. In addition to these analyses, samples of used bedding materials were taken monthly, immediately before refreshing with new bedding, and then analyzed for concentrations of DM and VS as described previously.

\section{Cow Measurements}

$B C S$. The body condition scoring system of Wildman et al. (1982) was used monthly to assess the body condition of each cow in the research barn. Cows were scored (scale: 1 to 5) on successive days by 2 different trained evaluators, where $1=$ emaciated and $5=$ obese, and increments of 0.5 units were applied to best define the body condition of each cow.

Cow Comfort. Cow comfort was assessed monthly, based on the system described by Cook et al. (2004, 2005). Each month, activities of all cows in each research pen were tabulated on consecutive days at $1100 \mathrm{~h}$ by 2 different observers. The following data were obtained: (1) total cows in each pen, (2) cows eating, (3) cows in stalls lying down, and (4) cows standing fully in the stalls (all 4 feet), and (5) cows perched in stalls (front 2 feet in the stall only). These inputs were obtained by counting in real time, and the following indices were calculated subsequently as indicators of cow comfort: (1) cow comfort index $=$ cows lying in stalls/all cows touching stalls $\times 100 \%$; (2) stall standing index $=$ cows standing in stalls (2 or 4 feet)/all cows touching stalls $\times 100 \%$; (3) stall usage index $=$ cows lying down in stalls/all cows not eating $\times 100 \%$; and (4) stall perching index $=$ cows standing with 2 feet in stalls/all cows touching stalls $\times 100 \%$.

Hock Score. As noted for BCS, hocks were scored for all cows each month by 2 trained evaluators using the Hock Assessment Chart for Cattle recommended by Cornell Cooperative Extension (Cornell University, Ithaca, NY). Using this concept, a score of $1=$ normal (no hair missing, no swelling), $2=$ hair loss on the hock (no swelling), and 3 = swelling or abrasions (or both) on the hock. For this visual assessment, only wholenumber scores $(1,2$, or 3$)$ were assigned for each cow.

Locomotion Scores. Cows were assessed monthly for lameness, based on the 4-point scale summarized by Cook (2003): (1) 1 = no gait abnormality, (2) $2=$ slight lameness, (3) $3=$ moderate lameness, and (4) 4 $=$ severe lameness. All cows were scored immediately before the evening milking ( $\sim 1600 \mathrm{~h}$ ) by a single trained evaluator, and all scores were assigned on a wholenumber basis only $(1,2,3$, or 4$)$. Each month, the percentage of cows within each pen with a locomotion score $>2$ (slight lameness) was calculated and reported as a separate response variable.

Cow Hygiene Scores. A measure of cow cleanliness was assessed for all cows once per month at $1100 \mathrm{~h}$ by 2 trained, independent observers. Scores were given for the upper leg and flank, lower leg, and the udder as described by Cook and Reinemann (2007). Generally, a score of $1=$ no manure or dirt, $2=$ slightly dirty $(2$ to $10 \%$ of surface area covered), $3=$ moderately dirty $(10$ to $30 \%$ of surface area covered), and $4=$ covered with caked-on dirt ( $>30 \%$ surface area covered). Hygiene scores were assigned to each cow without fractional increments $(1,2,3$, or 4$)$, and then averaged across the 2 evaluators before statistical analysis.

Hoof Trimming Statistics. All primiparous cows entering the trial were examined by a hoof trimmer approximately $60 \mathrm{~d}$ before parturition, and therefore entered the trial in approximately equivalent condition. For the lactating cows on trial, the hoof trimmer was on site at least quarterly. Cows were examined and treated as needed throughout their lactations, and all cows were examined when confirmed as pregnant at about $210 \mathrm{~d}$. During these examinations, counts were maintained for hoof repair and are reported as supporting observational data without statistical analysis.

Milk Production. Throughout the trial, cows were milked by pen group twice per day at 0445 and 1600 
$\mathrm{h}$, and milk weights were recorded daily. Monthly DHI data were obtained from one milking per month, where sampling on a month-to-month basis was alternated between the 0445 and $1600 \mathrm{~h}$ milkings; FCM and ECM daily milk yields were obtained from these data, where FCM and ECM milk yields were calculated from NRC (2001) equations. Concentrations of milk fat, protein, and MUN were determined by infrared analysis, and SCC by flow cytometry (AgSource Laboratories, Marshfield, WI) using a Combi-Foss $6600 \mathrm{FT}+/ \mathrm{FC}$ (Foss Electric, Hillerød, Denmark). Somatic cell scores were calculated as $\mathrm{SCS}=\log _{2}(\mathrm{SCC} / 100,000)+3$ (Shook, 1993). Furthermore, each mean SCS was then back-transformed into a raw SCC for information purposes, but was not analyzed statistically on that basis.

Mastitis. Cases of treatable mastitis were identified, and then treated according to standard operational procedures within the research barn as approved the Resource Animal Research Committee of the University of Wisconsin-Madison (Protocol \#A005374). Infections were characterized as grade 1,2 , or 3 , where (1) grade 1 = abnormal milk, but cows otherwise healthy; (2) grade 2 = abnormal milk, plus swollen udder or hard quarter; and (3) grade $3=$ abnormal milk, swollen udder or hard quarter, plus systemic sickness, such as reduced appetite, fever, lethargy, and so on. Infections were treated with various protocols approved by the attending veterinarian that were specific to the severity of the infection. Clinical cases of mastitis were documented for each bedding system within year and month-within-year for subsequent statistical analysis. In addition, milk samples from clinically infected quarters were cultured during 2014 by AgSource Laboratories and during 2015 and 2016 by Marshfield Labs (Marshfield Clinic, Marshfield, WI).

\section{Statistics}

Experimental Design. The experimental design for this study was an incomplete Latin square. A $4 \times 4$ Latin square was originally planned, with dimensions of the square being pen of the barn and calendar year. Initially, the 4 bedding systems were assigned to pen $\times$ year cells in a Latin square framework (i.e., each treatment appeared exactly once in each row and once in each column of the square). However, data accrual was terminated after 3 years based on time and labor considerations, as well as statistical consultation indicating that the incomplete Latin square design was not likely to limit the ability to evaluate treatment effects. Within each pen $\times$ year cell, monthly longitudinal measurements of analytic response variables were recorded for each cow. Because cows remained in the same pen for the duration of their lactation, and the lactation period for a given cow could cross year-end boundaries, individual cows could contribute data to (at most) 2 cells of the Latin square for a given lactation, provided they met the 30-d residence criteria described previously.

Physical Characteristics and Composition of Bedding Before Distribution. All analyses of bedding materials and manure deposited in alleys were conducted with PROC MIXED of SAS 9.4 (SAS Institute Inc., Cary, NC). Bedding materials (NSA, RSA, and OS) sampled each month before distribution within the freestalls were analyzed as a $3 \times 12$ factorial arrangement of bedding material and month (January through December) with 3 replications (years). The KenwardRodgers approximation was used to calculate degrees of freedom, and main effects of bedding material were compared with the following mutually orthogonal contrasts: (1) OS vs. NSA + RSA, and (2) NSA vs. RSA. Because each bedding material was obtained via purchase (new sand) or from regular processing/handling protocols for by-products of the manure system, and because sampling occurred before placement in the barn, this analysis was not considered to be a repeated measure.

Concentrations of DM and Volatile Solids in Used Bedding Materials. The concentration of DM within bedding materials at the stall surface is of particular interest, especially given the commonly held association between wet organic bedding materials, such as green sawdust, and coliform mastitis infections (Looper, 2012). Samples of bedding materials obtained from freestalls were analyzed in a manner similar to bedding materials before distribution, except that the analysis was considered to be a repeated measure, where the statement REPEATED / SUBJECT $=$ YEAR ${ }^{*}$ PEN $\mathrm{TYPE}=\mathrm{AR}(1)$ was added to the statistical analysis. Unlike bedding sampled on a pre-distribution basis, the bedding system $\times$ month interaction was significant $(P$ $=0.001$ ) for $\mathrm{DM}$ concentration; therefore, interaction means are reported and discussed. Bedding systems were compared within month with the following mutually orthogonal contrasts: (1) DBOS + MAT vs. NSA + RSA; (2) NSA vs. RSA; and (3) DBOS vs. MAT. The concentration of VS in used bedding materials was analyzed by similar procedures.

Manure Analysis. Manure samples obtained monthly from the feed and resting alleys within each pen were analyzed in a manner similar to used beddings, except that months were condensed to seasonal effects to maintain a more concise presentation of results. This also was considered to be a repeated measures analysis. Seasons were defined as (1) winter (January through March), (2) spring (April through June), (3) summer (July through September), and (4) fall (October 
through December), and seasonal means were separated by the diff option for LSMEANS by PROC MIXED of SAS. Bedding treatments were compared by mutually orthogonal contrasts: (1) DBOS + MAT vs. NSA + RSA, (2) NSA vs. RSA, and (3) DBOS vs. MAT.

Cow Performance, Welfare, and Hygiene. All analyses for cow-related response variables were carried out using PROC GLIMMIX (SAS Institute Inc.). Because the lactations of some cows crossed the changeover date dividing experimental periods, and because cows remained in their assigned pen at that time, there was potential for carryover effects from the previous treatment assignment. One-month carryover effects were determined, and appropriately accommodated when statistically significant at the $P \geq 0.05$ level of confidence. Initially, models for each response variable (without transformation) were fit and corresponding panels of residual plots were examined to evaluate whether violations of model assumptions were present. Transformations of response variables were undertaken when indicated, particularly for percentage data, using an arcsine square-root transformation, or as otherwise noted. Linear mixed models were fit, and the fixed effects included were bedding system, season, and the bedding system $\times$ season interaction, where seasonal designations were as described previously. For milk production measures, where data were longitudinal monthly measurements at the level of a cow, random effects included year, pen, year $\times$ pen, and cow. A firstorder autoregressive term was included to account for the correlation between monthly responses for a given cow within year and pen. For most cow welfare and hygiene response variables, data were aggregated at the level of month across cows. Random effects for these models were the same as described previously, except that the effect for cow was omitted, and the first-order autoregressive term corresponds to the aggregated monthly responses within year and pen. A significant carryover effect was observed only for hock score $(P=$ 0.034 ), and a fixed carryover effect was included in that model. All treatment comparisons examined for these response variables were mutually orthogonal, hence no multiple comparison adjustments were necessary. For the seasonal effect, all pairwise comparisons were examined and the Tukey-Kramer multiple comparison adjustment was applied (Kramer, 1956). Unlike other production, welfare, and hygiene data, the number of mastitis cases, a response variable that assumed nonnegative integer values $(0,1,2$, and so on), was analyzed using mixed Poisson regression. Significance was declared throughout all analyses at the $P \leq 0.05$ level of confidence; trends of interest were identified and discussed at $P \leq 0.10$.

\section{RESULTS AND DISCUSSION}

\section{Physical Characteristics and Composition of Bedding}

Before Distribution. Before placement in the freestalls, statistical analysis of the physical characteristics and composition of bedding materials indicated that a tendency $(P=0.059)$ for the main effect of month was observed for the density of bedding, but not for any other response variable $(P \geq 0.171)$. Similarly, the bedding material $\times$ month interaction $(P \geq$ 0.298 ) did not approach significance for any physical or compositional characteristic. To maintain a concise presentation of results, only main-effect means for bedding material are presented (Table 2) and discussed. All measures of physical characteristics and nutrient composition differed sharply $(P \leq 0.001)$ between OS and sand-bedding materials, with OS exhibiting lower concentrations of DM (36.5 vs. $94.3 \%)$ and density (0.50 vs. $1.56 \mathrm{~g} / \mathrm{cm}^{3}$ ), but a greater (more basic) pH (8.99 vs. 7.01), as well as greater nutrient concentrations for all variables evaluated. Although NSA and RSA differed numerically for some aspects of nutrient composition, these responses were not statistically significant $(P \geq$ $0.308)$. However, the $\mathrm{pH}$ of NSA was more acidic than RSA (6.87 vs. $7.16 ; P=0.028)$. Overall, the DM concentration of OS measured in the present study $(36.5 \%)$ was similar to that reported by Husfeldt et al. (2012), which ranged from 27.1 to $39.7 \%$ for digested, composted, or raw OS.

After Distribution. Concentrations of DM (Table 3) within bedding materials sampled directly from freestalls on a monthly basis reflected the inorganic nature of sand bedding. The DM concentration of NSA and RSA was $\geq 90.5 \%$ across all months, and greater $(P<0.001)$ across all months than OS or MAT, which ranged from 35.5 to $67.4 \%$. No differences $(P \geq 0.399)$ were observed between NSA and RSA for any month of the year. The contrast of deep versus shallow bedding of OS was evident throughout the summer months; concentrations of DM were greater $(P \leq 0.047)$ for MAT compared with DBOS from May through October with the difference between OS-bedding systems ranging from 9.9 to 22.7 percentage units. This was likely explained by greater exposure to air for shallow-bedded MAT, which facilitated drying relative to DBOS. For VS, neither the main effect of sampling month, nor the interaction of main effects $(P \geq 0.830)$, was significant. The 3-yr mean concentrations of VS (data not shown) were $69.1,81.6,1.2$, and 1.8\% (DM basis) for DBOS, MAT, NSA, and RSA, respectively. The VS within bedding systems with OS differed from sand (75.4 vs. 1.5\%; 
Table 2. Analysis of 3 bedding materials sampled before use in freestalls at Stratford, Wisconsin, from 2014 through 2016

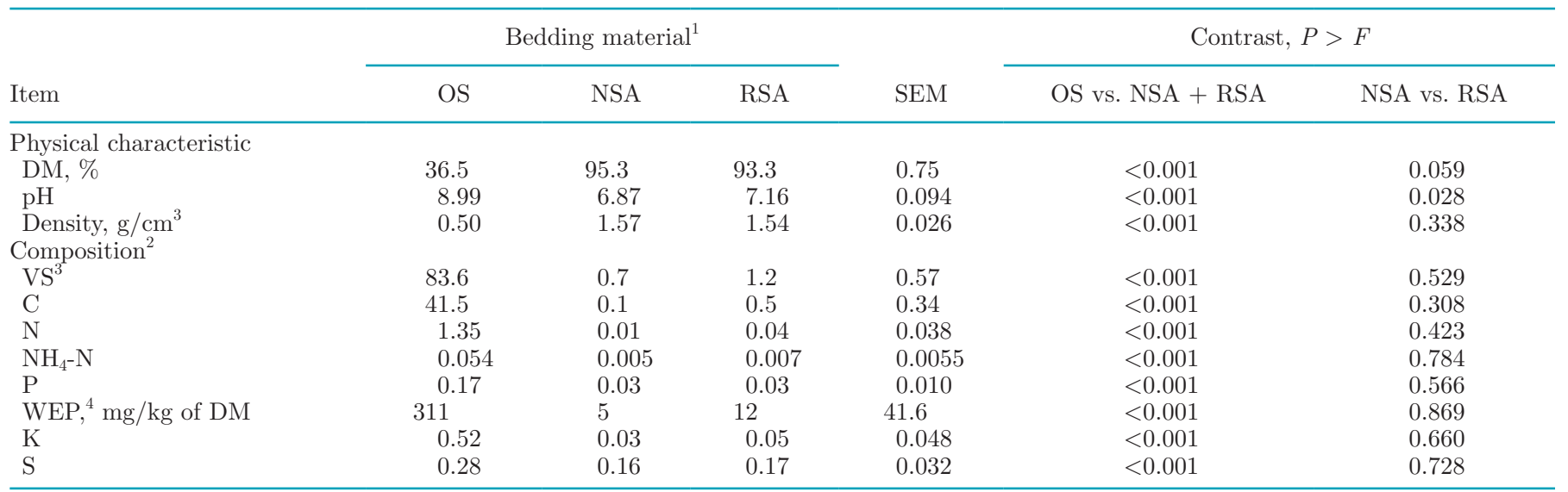

${ }^{1} \mathrm{OS}=$ organic manure solids; NSA $=$ new sand; RSA = recycled sand. For this trial, OS and RSA were recycled by-products of manure processing.

${ }^{2}$ Expressed on a $\%$ of DM basis, unless otherwise indicated.

${ }^{3} \mathrm{VS}=$ percentage of DM lost on combustion in a muffle furnace at $500^{\circ} \mathrm{C}$ for $2 \mathrm{~h}$.

${ }^{4} \mathrm{WEP}=$ water-extractable $\mathrm{P}$.

$P<0.001)$, and DBOS differed from MAT $(P<0.001)$, but sand-bedding systems did not differ $(P=0.797)$.

\section{Manure from Alleys}

Feed Alley. Largely because of the sand-bedding materials displaced into the manure alley, the DM concentration of manure from the feed alley was greater for sand-bedding systems compared with those using OS (Table 4; 33.7 vs. $14.1 \% ; P<0.001$ ). Similarly, the density of manure from sand-bedded systems was $17 \%$ greater than observed for OS-bedding systems (1.23 vs. $\left.1.05 \mathrm{~g} / \mathrm{cm}^{3} ; P<0.001\right)$. In contrast, manure obtained from bedding systems using OS contained sharply greater $(P \leq 0.001)$ concentrations of all nutrients compared with manure obtained from sand-bedded systems. This was particularly evident with respect to $\mathrm{VS}, \mathrm{N}, \mathrm{NH}_{4}-\mathrm{N}$, $\mathrm{K}$, and $\mathrm{C}$ for which concentrations ranged from roughly 2 to 3 times greater than those from sand-bedded systems. Although statistical significance was observed for the seasonal main effect for all response variables $(P \leq 0.027)$ except density $(P=0.109)$ and $\mathrm{C}(P=$

Table 3. Concentrations of DM in used freestall bedding sampled between January 2014 and December 2016 at Stratford, Wisconsin

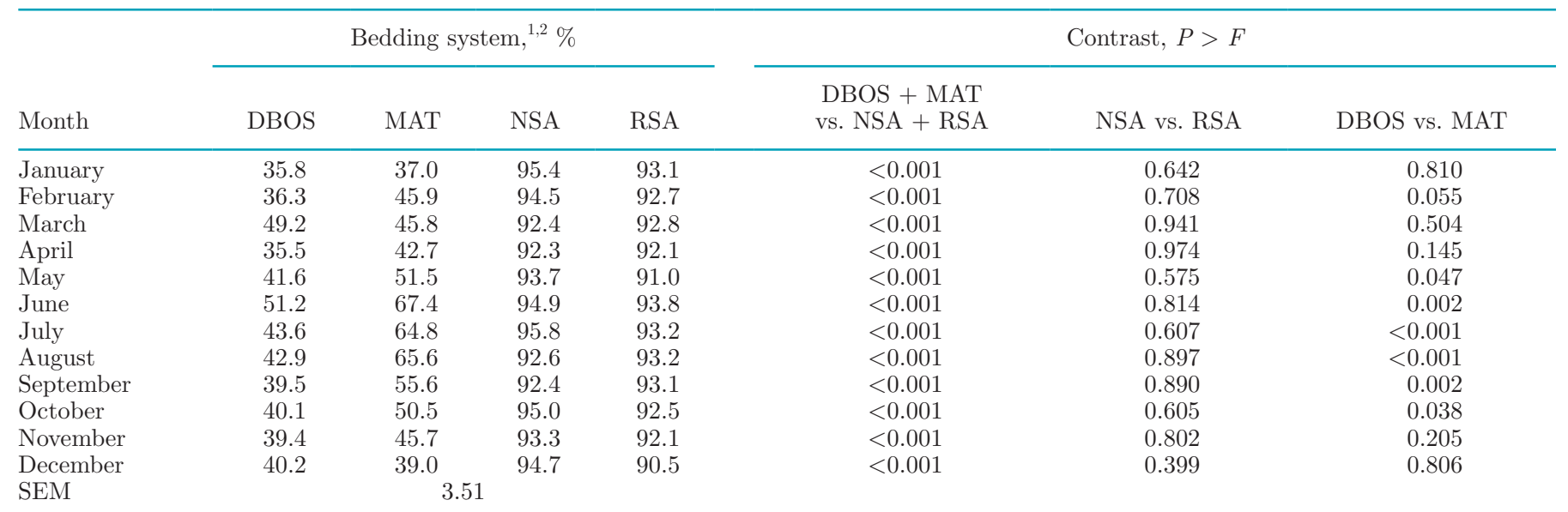

${ }^{1}$ Bedding system: DBOS = deep-bedded organic solids; MAT = organic solids spread over foam-core mattresses; NSA = deep-bedded new sand; and RSA = deep-bedded recycled sand recovered from the screw-type sand separator.

${ }^{2}$ Concentrations of volatile solids for bedding systems also were determined and were affected by bedding system $(P<0.001)$ but not sampling month or the interaction of main effects $(P \geq 0.830)$. Three-year means for bedding systems $(\mathrm{n}=36$ mo $)$ were $69.1,81.6,1.2$, and $1.8 \%$ of $\mathrm{DM}$ for DBOS, MAT, NSA, and RSA, respectively. Analysis of contrasts indicated: DBOS + MAT vs. NSA + RSA differed at $P<0.001 ;$ DBOS vs. MAT differed at $P<0.001 ;$ NSA vs. RSA did not differ $(P=0.797)$. 
0.107), the effects of season were less discernible than those of bedding system. In most cases, seasonal differences were relatively minor in scope, but several are worthy of special note because they are directly related to reduced evaporation or volatilization during winter months. Specifically, the DM concentration of manure during winter months was reduced $(P \leq 0.010)$ by 4.0 to 4.9 percentage units compared with other seasons, and concentrations of $\mathrm{N}(2.46 \%)$ and $\mathrm{NH}_{4}-\mathrm{N}(1.24 \%)$ were greatest $(P<0.001)$ during winter months, when volatilization was likely limited by colder temperatures. Concentrations of $\mathrm{N}$ and $\mathrm{NH}_{4}-\mathrm{N}$ during seasons other than winter ranged from 1.98 to $2.11 \%$ and 0.83 to $0.90 \%$, respectively.

Resting Alley. Although not compared statistically, manure obtained from routine monthly sampling of the resting alley (Table 5) generally exhibited reduced nutrient concentrations compared with the feed alley. Of particular note were concentrations of $\mathrm{N}, \mathrm{NH}_{4}-\mathrm{N}$, WEP, and $\mathrm{C}$ from sand-bedding systems, which ranged from 49.0 to $61.3 \%$ of those observed from the corresponding feed alley. Despite this observation, the $\mathrm{C} / \mathrm{N}$ ratio in manure from the resting alley was numerically greater across all bedding systems, increasing by 8.3 to $13.8 \%$ relative to the feed alley. For the resting alley, physical characteristics and nutrient composition of manure yielded a significant $(P<0.001)$ main effect of bedding system for all response variables except $\mathrm{pH}$ (mean = 8.27; $P=0.999$ ). This was associated directly with the sharp contrasts between OS and sand-based bedding systems, which were significant $(P<0.001)$ for all response variables except $\mathrm{pH}(P=0.944)$. Within sandbedded systems, NSA differed from RSA with respect to DM (49.0 vs. $43.8 \% ; P<0.001)$ and density (1.40 vs. $\left.1.34 \mathrm{~g} / \mathrm{cm}^{3} ; P=0.005\right)$, but not for any other response variable $(P \geq 0.213)$. In contrast, DBOS and MAT bedding systems differed for total N (2.42 vs. $2.79 \%$; $P<$ $0.001), \mathrm{NH}_{4}-\mathrm{N}(0.95$ vs. $1.13 \% ; P=0.002), \mathrm{P}(0.58$ vs. $0.66 \% ; P<0.001)$, and $\mathrm{K}(1.57$ vs. $1.73 \% ; P=0.013)$ with the greatest concentrations observed for MAT in each case. Seasonally, the most important observation was the reduced $(P \leq 0.001)$ concentrations of $\mathrm{NH}_{4} \mathrm{~N}$ that were observed during warmer spring and summer months compared with fall and winter, when colder temperatures likely limited volatilization.

\section{Cow Welfare}

Body Condition Score. Contrasts of bedding systems (Table 6) comparing the BCS of lactating cows were not significant $($ mean $=2.77 ; P \geq 0.071$ ), but there was a tendency for greater BCS on sand-bedded systems compared with those utilizing OS (2.82 vs. $2.73 ; P=0.071)$. Seasonally, BCS was greater during fall than winter $(2.85$ vs. $2.70 ; P=0.046)$, and intermediate between those extremes during spring and summer, although those seasons did not differ $(P \geq$ 0.278 ) from either extreme.

Assessments of Stall Usage. Cow comfort index, defined as cows lying in stalls expressed as a percentage of those touching stalls, was greater for sand-bedded systems compared with those using OS (88.4 vs. 82.8\%; $P=0.002)$; however, contrasts comparing cow comfort indexes within common bedding materials (NSA vs. RSA or DBOS vs. MAT) did not differ $(P \geq 0.190)$. Although cow comfort index was numerically lower in summer than observed for other (cooler) seasons, no seasonal statistical differences were detected (mean $=85.7 \% ; P \geq 0.053)$. Stall standing index, which has been associated with lame cow behavior when the index is $>20 \%$ if assessed $2 \mathrm{~h}$ before the morning or afternoon milkings (Cook et al., 2004), was $<20 \%$ for all bedding systems and during all seasons of the year, but was greater for bedding systems with OS compared with sand (17.2 vs. $11.6 \% ; P=0.002)$. For this study, stall standing index for MAT (18.8\%) was somewhat less than reported for cows housed on rubber crumb-filled geotextile mattresses as reported by Cook et al. (2004; $23.9 \%$ ). The stall usage index, defined as cows lying down expressed as a percentage of all cows not eating did not exhibit detectable contrasts for bedding system $($ mean $=69.6 \% ; P \geq 0.062)$, but was greater $(P$ $\leq 0.014)$ during fall and winter than observed during summer. The stall perching index, defined as the number of cows standing with 2 feet in the stall expressed as a percentage of all cows touching stalls, was $\leq 5.5 \%$ for all bedding systems and seasons. A weak effect was detected for the comparison of bedding systems using OS compared with sand-based bedding systems (5.0 vs. $3.2 \% ; P=0.048)$, but no differences were detected between DBOS and MAT $(P=0.467)$ or NSA and RSA $(P=0.241)$. No differences $(P \geq 0.564)$ were detected among seasonal means. The stall perching index observed for this trial $(\leq 5.5 \%)$ is substantially less than that reported by Cook et al. (2004) for sand- (12.6\%) and mattress-bedded (9.4\%) herds in Wisconsin. Results from that previous study suggest that perching and standing activity in stalls may be independent of each other with perching being predominantly a function of stall design, whereas standing activity may be more associated with lameness.

Hock and Locomotion Scores. Main effects of bedding system $(P<0.001)$ and season $(P<0.001)$ affected hock scores. In addition, this was the only response variable to demonstrate a significant carryover effect $(P=0.034)$ from the bedding system used during the previous experimental period, which was linked directly to use of mattresses in stalls. Cows bedded in 
DAIRY INDUSTRY TODAY

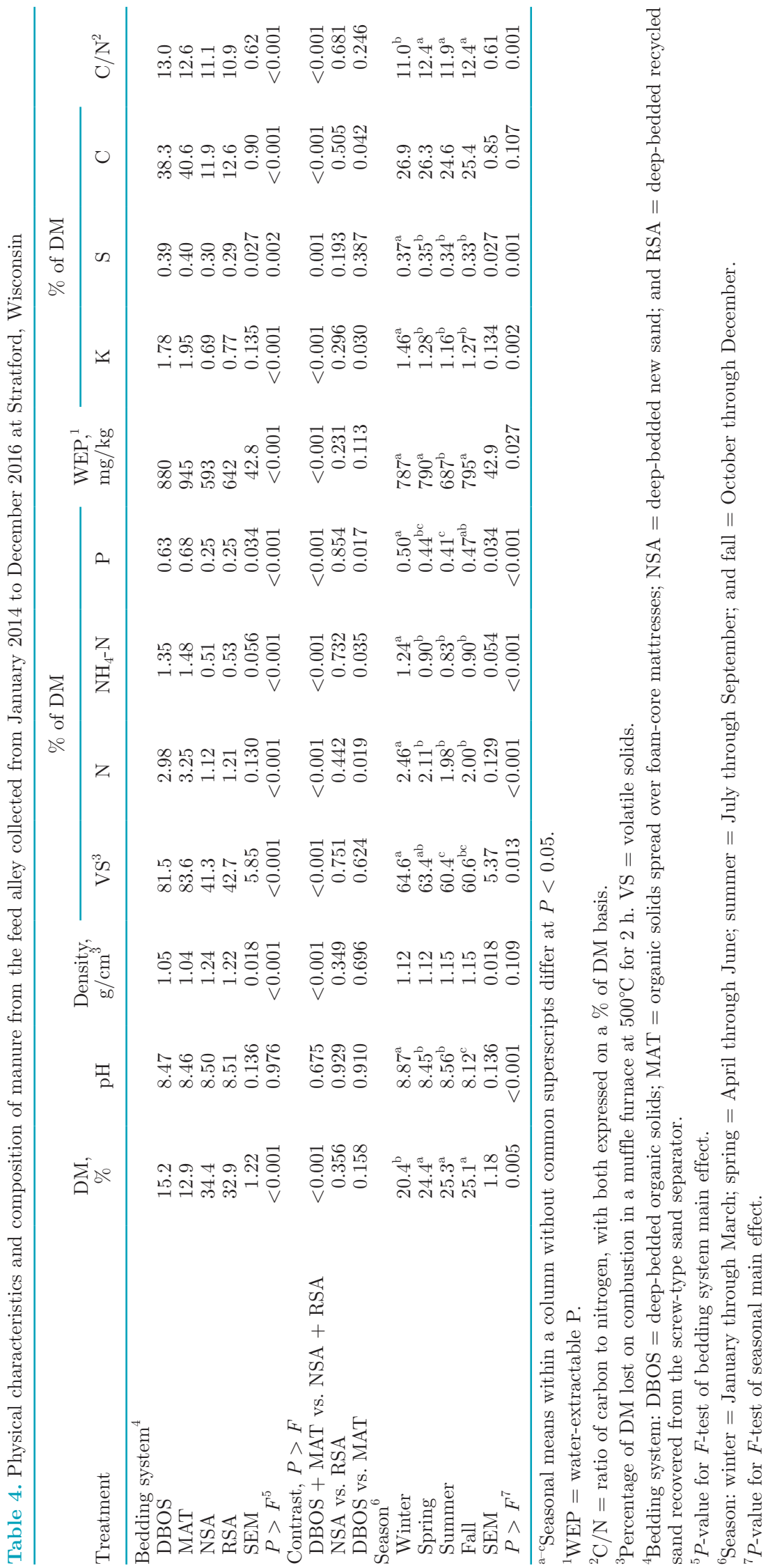


ESSER ET AL.

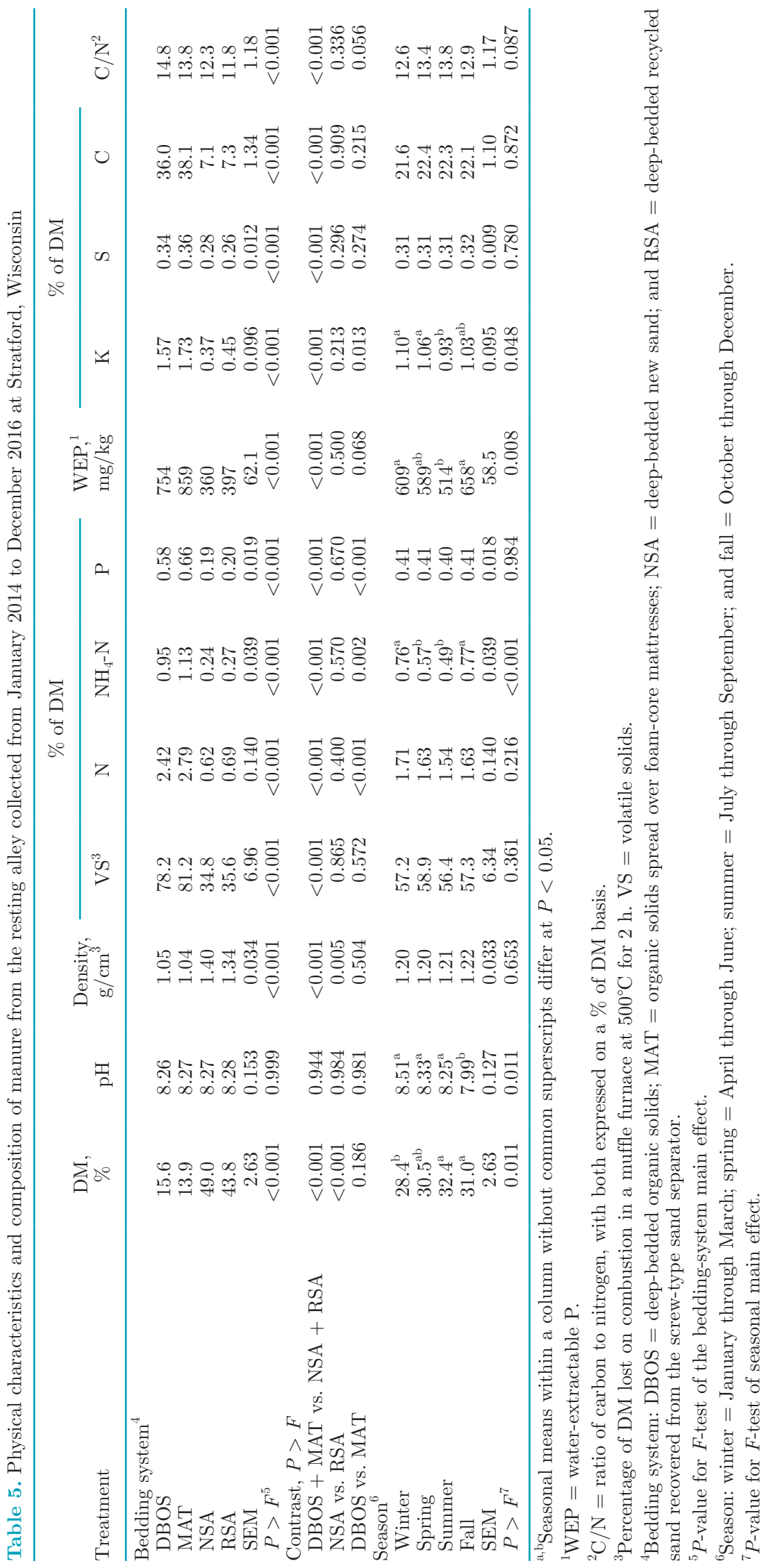


DAIRY INDUSTRY TODAY

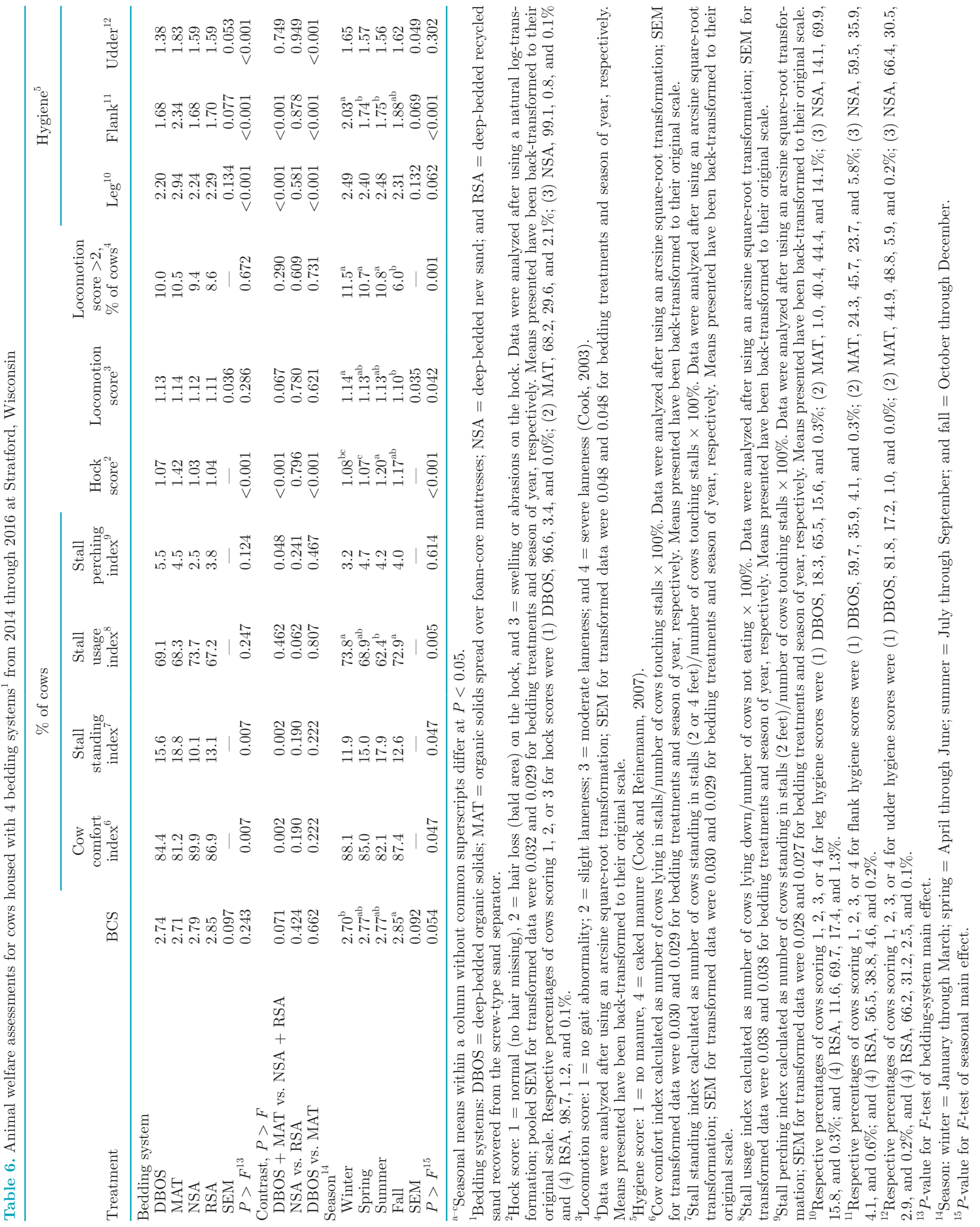


systems using OS exhibited greater mean hock scores than those from sand-based systems (1.25 vs. 1.04; $P<$ 0.001 ), but this effect was entirely associated with use of mattresses (MAT), which differed sharply from DBOS (1.42 vs. $1.07 ; P<0.001)$. Use of foam mattresses has been associated with elevated hock injuries in previous studies when compared against deep-bedded materials (van Gastelen et al., 2011; Husfeldt and Endres, 2012). Throughout the study, hock scores remained low, with monthly assessments indicating $\geq 96.6 \%$ of all cows assigned to the NSA, RSA, and DBOS bedding treatments scored $<2$. A score of 2 is indicative of any size area on the hock that is devoid of hair (Cornell University, Ithaca, NY). For the MAT bedding system, the mean hock score (1.42) was somewhat greater, with $31.7 \%$ of cows scoring $\geq 2$, but only a small percentage $(2.1 \%)$ exhibited swelling or lesions (hock score $=$ 3 ). Throughout the $3-y r$ trial, a total of 21 cows were scored 3; of these, 19 were assigned to the MAT bedding system. A recent survey study (Cook et al., 2016) found the mean farm-level prevalence of injured hocks (hock score $\geq 2$ ) was $50.3 \pm 28.3 \%$, with $12.2 \pm 15.3 \%$ exhibiting a score $\geq 3$. In the present study, hock scores also were greater $(P \leq 0.006)$ during summer $(1.20)$ compared with winter (1.08) or spring (1.07), but on a practical basis, these differences were relatively minor.

Neither locomotion score $($ mean $=1.13)$, nor the percentage of cows exhibiting a locomotion score $>2$ $($ mean $=9.6 \%)$, exhibited detectable contrasts when comparing bedding systems $(P \geq 0.067)$. A locomotion score of 2 represents only mild or slight lameness (Cook, 2003), and our low scores also may partially reflect the near-complete primiparous nature of the herd. A seasonal effect was detected for locomotion score, with a greater score observed during winter compared with fall (1.14 vs. $1.10 ; P=0.027)$; other seasons were intermediate between those narrow extremes. Similarly, the percentage of cows with scores $>2$ was less $(P \leq$ $0.007)$ during fall $(6.0 \%)$ compared with all other seasons $($ mean $=11.0 \%)$.

Hygiene. Generally, hygiene scores for legs, flanks, and udders were numerically similar for the DBOS, NSA, and RSA bedding systems. Differences between bedding systems were associated entirely with MAT, yielding detectable contrasts between MAT and DBOS for legs (2.94 vs. $2.20 ; P<0.001)$, flanks (2.34 vs. 1.68; $P<0.001)$, and udders (1.83 vs. $1.38 ; P<0.001)$. A seasonal main effect $(P<0.001)$ was observed for flanks, in which scores were greater $(P \leq 0.002)$ during winter compared with spring and summer; however, the range across all seasons was narrow (1.74 to 2.03). In a previous report, Cook and Reinemann (2007) reported a median of $19 \%$ of cows scoring either 3 or 4 for udder hygiene in a study of 46 Wisconsin dairy herds housed in freestalls, and a median of $11 \%$ within a subset of the $25 \%$ of herds exhibiting the best hygiene. Within the same report, a comparison of herds with sand- and mattress-based freestalls ( $\mathrm{n}=6$ of each system) found the mean percentage of udder hygiene scores $\geq 3$ to be $16.7 \%$ of cows using sand bedding, but about twice that percentage $(33.3 \%)$ for those reclining on mattresses. Furthermore, using a similar udder-hygiene evaluation system, Schreiner and Ruegg (2003) found the distribution of udder hygiene scores across 8 Wisconsin dairies to be $20.4,58.0,14.2$, and $7.4 \%$ for scores $1,2,3$, and 4 , respectively. In the same study, cows with udder hygiene scores of 3 or 4 were 1.5 times more likely to have major pathogens isolated from milk. In the present study, udder hygiene scores of either 3 or 4 were observed for $3.1,2.6,1.0$, or $6.1 \%$ of cows assigned to NSA, RSA, DBOS, or MAT bedding systems, respectively; these percentages are lower than those cited in the aforementioned Wisconsin studies with commercial herds. Since the percentage of cows scoring 3 or 4 was relatively low for MAT, the previously mentioned difference between DBOS and MAT for mean udder hygiene scores can be explained on the basis of respective percentages of scores 1 or 2 (no dirt or slightly dirty; Cook and Reinemann, 2007), which were 81.8 and $17.2 \%$ for DBOS (Table 6 ), but almost equivalent for MAT (44.9 and 48.8\%). For leg hygiene scores, the percentage of cows scoring 3 or 4 was almost identical for the NSA, RSA, and DBOS bedding systems (16.1, 18.7 , and $15.9 \%$, respectively) compared with MAT (58.5\%), and a similar disproportionate response was observed for flanks $(29.5 \%$ for MAT, $<5 \%$ for all other bedding systems). Taken in total, udder and overall hygiene from mostly primiparous cows in the present study was generally comparable or superior to that observed on commercial dairies, and the poorer hygiene observed for MAT compared with deep-bedded systems was consistent with trends observed in past studies.

\section{Documentation of Hoof-Trimming Statistics}

A summary of hoof-trimming services is provided (Table 7) without comparative statistics; total cows treated over 3 yr were numerically greater for DBOS (348 cows) and MAT (349 cows) than for NSA (259 cows) or RSA (315 cows). Most incidents were related to imbalance, which was about $27 \%$ more frequent with bedding systems using OS. The increased incidence of hoof treatment for RSA compared with NSA was largely associated with correction of thin sole for RSA-bedded cows. This observation may have been associated with the more abrasive nature of RSA compared with NSA after displacement into the concrete alleyways by the cows. 
Table 7. Documentation of hoof trimming statistics ${ }^{1}$ for cows housed with 4 bedding systems ${ }^{2}$ from January 2014 through December 2016 at Stratford, Wisconsin

\begin{tabular}{|c|c|c|c|c|}
\hline Item & DBOS & MAT & $\mathrm{NSA}$ & RSA \\
\hline Abscess & 8 & 4 & 2 & 0 \\
\hline Hemorrhage/bruise & 1 & 1 & 2 & 0 \\
\hline Hemorrhage/sole & 1 & 11 & 4 & 2 \\
\hline Interdigital corn & 5 & 7 & 2 & 5 \\
\hline Dermatitis & 74 & 69 & 59 & 62 \\
\hline Heel erosion & 3 & 0 & 1 & 4 \\
\hline Imbalance & 233 & 236 & 178 & 192 \\
\hline Corkscrew & 10 & 6 & 5 & 16 \\
\hline Ulcer/toe & 2 & 1 & 0 & 1 \\
\hline Ulcer/sole & 3 & 4 & 2 & 0 \\
\hline Thin sole & 2 & 1 & 2 & 32 \\
\hline Sole fracture & 0 & 2 & 0 & 0 \\
\hline Interdigital foot rot & 1 & 0 & 0 & 0 \\
\hline Block & 5 & 7 & 2 & 1 \\
\hline Total (all categories) & 348 & 349 & 259 & 315 \\
\hline
\end{tabular}

${ }^{1}$ Three-year cumulative counts of various hoof problems from January 2014 through December 2016; numbers represent counts provided by the hoof trimmer on a quarterly basis, and no statistical analysis has been applied to the data.

${ }^{2}$ Bedding system: DBOS $=$ deep-bedded organic solids; MAT $=$ organic solids spread over foam-core mattresses; NSA = deep-bedded new sand; and RSA = deep-bedded recycled sand recovered from the screw-type sand separator.

\section{Milk Yield and Quality}

No significant contrasts comparing bedding systems were detected for milk yield (mean $=34.0 \mathrm{~kg} / \mathrm{d} ; P \geq$ $0.269)$, ECM $($ mean $=36.1 \mathrm{~kg} / \mathrm{d} ; P \geq 0.237), 3.5 \%$ FCM $($ mean $=36.9 \mathrm{~kg} / \mathrm{d} ; P \geq 0.219)$, milk fat percentage $($ mean $=3.91 \% ; P \geq 0.800)$, milk protein percentage $($ mean $=3.15 \% ; P \geq 0.114)$, MUN $($ mean $=12.0$ $\mathrm{mg} / \mathrm{dL} ; P \geq 0.310$ ), SCS (mean $=1.79 ; P \geq 0.523$ ), or percentage of cows with $\mathrm{SCC}>200,000$ cells $/ \mathrm{mL}$ (mean $=6.5 \% ; P \geq 0.138$; Table 8). However, modest seasonal differences were detected, with yield of ECM, 3.5\% FCM, and MUN greatest $(P<0.002)$ during spring. Milk fat percentage and SCS also were numerically greatest during spring, but did not differ $(P \geq 0.076)$ from fall in either case. Milk protein percentage was greatest $(P \leq 0.001)$ during fall $(3.23 \%)$, followed by spring $(3.17 \%)$, which was greater $(P \leq 0.001)$ than observed for other seasons. Seasonal means for milk yield and percentage of cows with SCC $>200,000$ cells/ $\mathrm{mL}$ did not differ $(P \geq 0.106)$. As such, the elevated hock scores and poorer hygiene scores for flanks, legs, and udders of cows using MAT had no overall detectable effects on measures of milk production.

\section{Mastitis Cases}

Documented cases of mastitis requiring treatment ranged from a low rate of 7.4 cases/yr for RSA to a high of 23.1 cases/yr for DBOS, based on a mean enrollment of 60.7 to 63.0 cows/treatment per yr (Table 9). Cows bedded with OS exhibited a greater incidence of mas- titis than those bedded with sand (19.0 vs. 8.4 cases/ yr; $P=0.012)$, but no differences $(P \geq 0.219)$ were observed for comparisons within individual beddingmaterial types. Differences were also observed among seasonal means with respect to mastitis; incidence was greater $(P \leq 0.031)$ during winter $(17.3$ cases $/ y r)$ and summer (16.1 cases/yr) than observed for spring (7.0 cases/yr). Incidence during fall was intermediate $(12.2$ cases/yr) between both extremes, and differed from neither $(P \geq 0.461)$. Over the 3 -yr trial, 40 cases of Klebsiella were documented from infected quarters; of these, 25 cases $(62.5 \%)$ occurred in cows assigned to the DBOS bedding system, whereas the remaining cases were distributed relatively evenly across the other 3 bedding systems.

In a shorter-term trial conducted in the same research facility, Rowbotham and Ruegg (2016a) observed no statistical differences between incidence of clinical mastitis across DBOS, MAT, NSA, or RSA bedding systems; however, the clinical incidence rate for NSA was only about one-third of that observed for the other 3 bedding systems. Furthermore, quarters of primiparous cows bedded on NSA tended to exhibit greater survival times until the first incidence of clinical mastitis compared with the RSA or DBOS bedding systems. For total (subclinical and clinical) mastitis, incidence rates for RSA and MAT were $56 \%$ greater than observed for NSA and DBOS; however, under the experimental conditions of the study, these differences again were not statistically significant.

Previously, Rowbotham and Ruegg (2016b) reported that numbers of streptococci-like organisms were 
ESSER ET AL.

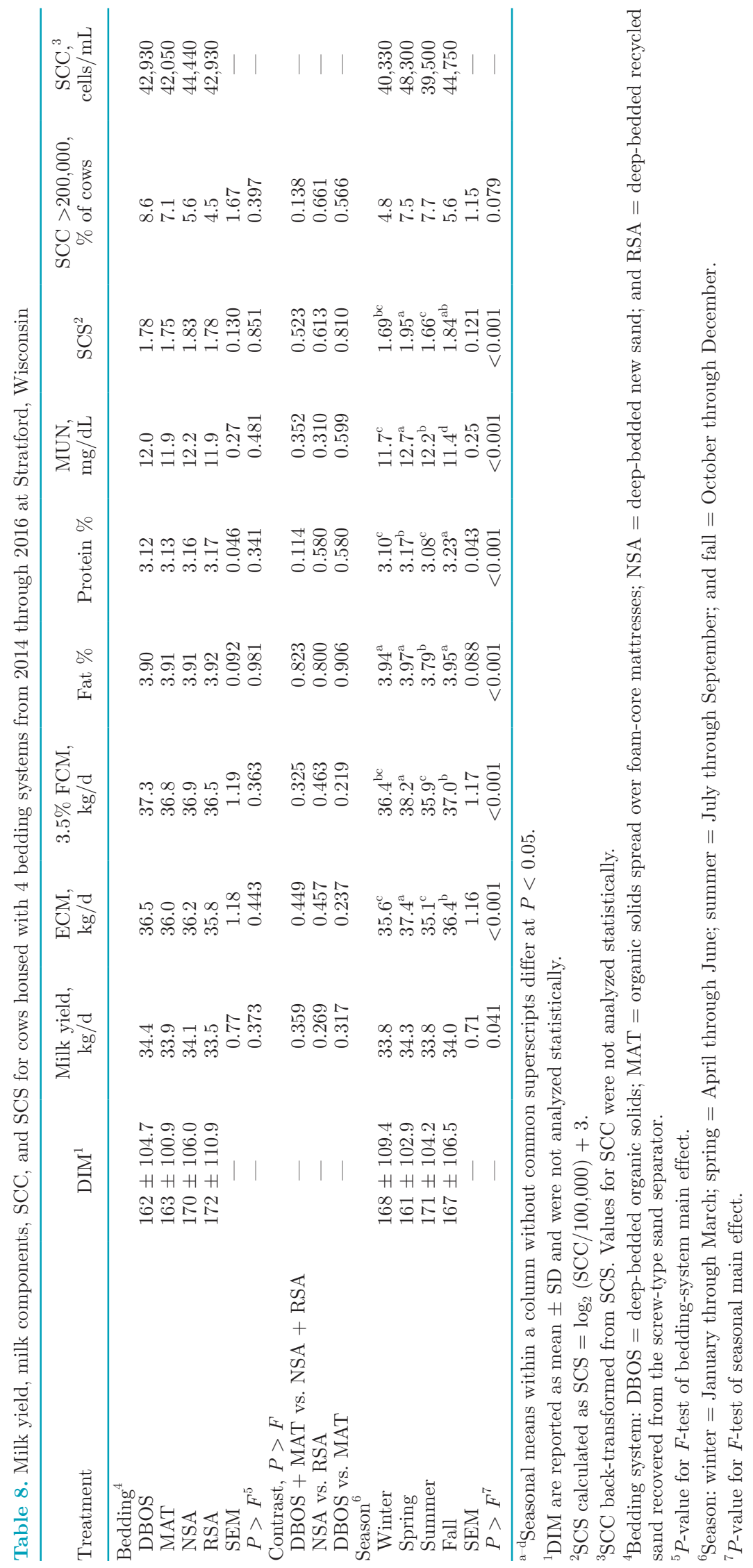


Table 9. Summary of mastitis cases ${ }^{1}$ incurred by lactating cows housed in freestalls on 4 bedding systems at Stratford, Wisconsin

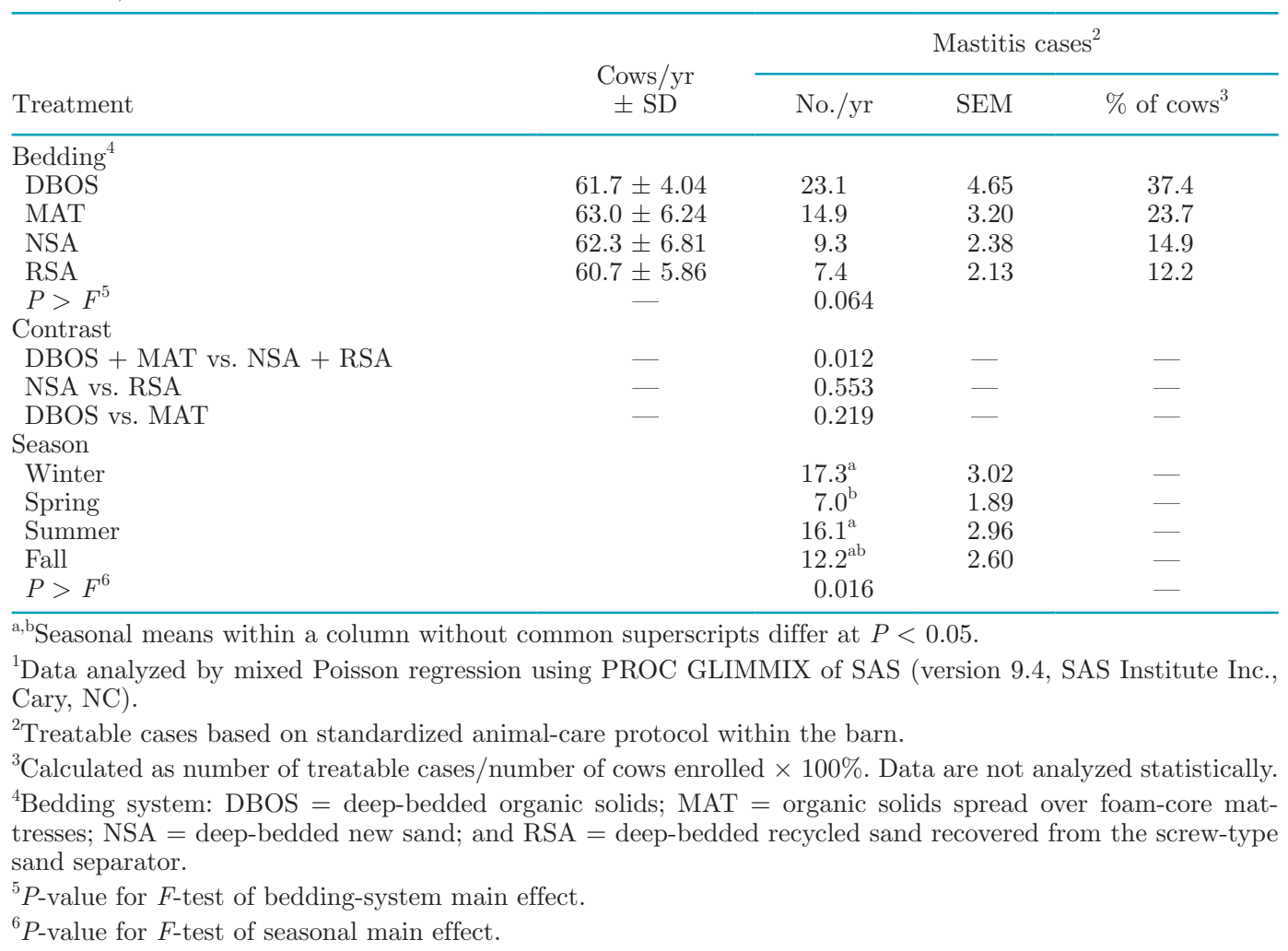

greater for MAT than for DBOS, NSA, or RSA, but numbers of coliforms were greatest for DBOS, and least in NSA. However, high bacterial populations do not definitively lead to udder infection when good management practices are employed (Fairchild et al., 1982). Furthermore, Rowbotham and Ruegg (2016b) found that numbers of all types of bacteria on postpreparation teat swabs were reduced by $2.6 \operatorname{logs}$, thereby confirming the value of effective pre-milking preparatory procedures for cows housed on bedding systems identical to those in the present study. As observed by Rowbotham and Ruegg (2016b), it is sometimes difficult to establish clear (statistical) cause-and-effect relationships between bacterial populations within bedding materials and the frequency of udder infections.

\section{CONCLUSIONS}

Generally, differences between bedding systems with respect to cow welfare, comfort, hygiene, milk production, and mastitis favored use of sand-bedding materials over systems using OS. The use of OS resulted in greater numbers of mammary infections than observed for either NSA or RSA bedding systems. Further evaluation of preparatory, handling, and usage procedures for OS may offer some opportunity to minimize health risks associated with OS bedding systems. Although the health and well-being of cows assigned to bedding systems using OS often were within typical thresholds of acceptable management, it is important to note that $99 \%$ of the enrolled cows in this study were primiparous, and that normal markers for acceptable management are based on cow herds that usually have majorities of multiparous cows.

\section{ACKNOWLEDGMENTS}

Mention of trade names or commercial products in this article is solely for the purpose of providing specific information, and does not imply either recommendation or endorsement by the US Department of Agriculture. The USDA is an equal opportunity provider and employer. This research was supported through appropriated USDA-Agricultural Research Service CRIS funds (project \#5090-12630-005-00D) and Specific Cooperative Agreement \#58-3655-1-0755.

\section{REFERENCES}

Adams, A. E., J. E. Lombard, C. P. Fossler, I. N. Román-Muniz, and C. A. Kopral. 2017. Associations between housing and management practices and the prevalence of lameness, hock lesions, and thin cows on US dairy operations. J. Dairy Sci. 100:2119-2136. 
AOAC. 1998. Official Method \#990.03. Official Methods of Analysis. 16th ed. AOAC, Arlington, VA.

Bewley, J. M., L. M. Robertson, and E. A. Eckelkamp. 2017. A 100year review: Lactating dairy cattle housing management. J. Dairy Sci. 100:10418-10431

Brotzman, R. L., D. Döpfer, M. R. Foy, J. P. Hess, K. V. Nordlund, T. B. Bennett, and N. B. Cook. 2015. Survey of facility and management characteristics of large, Upper Midwest dairy herds clustered by Dairy Herd Improvement records. J. Dairy Sci. 98:8245-8261.

Chapinal, N., A. K. Barrientos, M. A. G. von Keyserlingk, E. Galo, and D. M. Weary. 2013. Herd-level risk factors for lameness in freestall farms in the northeastern United States and California. J. Dairy Sci. 96:318-328.

Cole, K. J., and J. S. Hogan. 2016. Short communication: Environmental mastitis pathogen counts in freestalls, bedded with composted and fresh recycled manure solids. J. Dairy Sci. 99:1501-1505.

Cook, N. B. 2003. Prevalence of lameness among dairy cattle in Wisconsin as a function of housing type and stall surface. J. Am. Vet. Med. Assoc. 223:1324-1328.

Cook, N. B., T. B. Bennett, and K. V. Nordlund. 2004. Effect of free stall surface on daily activity patterns in dairy cows with relevance to lameness prevalence. J. Dairy Sci. 87:2912-2922.

Cook, N. B., T. B. Bennett, and K. V. Nordlund. 2005. Monitoring indices of cow comfort in free-stall housed dairy herds. J. Dairy Sci. 88:3876-3885.

Cook, N. B., J. P. Hess, M. R. Foy, T. B. Bennett, and R. L. Brotzman. 2016. Management characteristics, lameness, and body injuries of dairy cattle housed in high-performance dairy herds in Wisconsin. J. Dairy Sci. 99:5879-5891.

Cook, N. B., and D. J. Reinemann. 2007. A toolbox for assessing cow udder, and teat hygiene. Pages 31-43 in Proc. 46th Annual Mtg. Natl. Mastitis Council, San Antonio, TX. Natl. Mastitis Council, Madison, WI.

Fairchild, T. P., B. J. McArthur, J. H. Moore, and W. E. Hylton. 1982. Coliform counts in various bedding materials. J. Dairy Sci. 65:1029-1033

Hogan, J. S., L. Raubenolt, J. L. McCormick, and W. P. Weiss. 2012. Evaluation of propane flaming for reducing bacterial counts in sand bedding. J. Dairy Sci. 95:6152-6159.

Husfeldt, A. W., and M. I. Endres. 2012. Association between stall surface and some animal welfare measurements in freestall dairy herds using recycled manure solids for bedding. J. Dairy Sci. 95:5626-5634.

Husfeldt, A. W., M. I. Endres, J. A. Salfer, and K. A. Janni. 2012. Management and characteristics of recycled manure solids used for bedding in Midwest freestall dairy herds. J. Dairy Sci. 95:21952203
Kleinman, P., D. Sullivan, A. Wolf, R. Brandt, Z. Dou, H. Elliott, J. Kovar, A. Leytem, R. Maguire, P. Moore, L. Saporito, A. Sharpley, A. Shober, T. Sims, J. Toth, G. Toor, H. Zhang, and T. Zhang. 2007. Selection of a water extractable phosphorus test for manures and biosolids as an indicator of runoff loss potential. J. Environ. Qual. 36:1357-1367.

Kramer, C. Y. 1956. Extension of multiple range tests to group means with unequal numbers of replications. Biometrics 12:307-310.

Looper, M. L. 2012. Reducing somatic cell count in dairy cattle. \#FSA4002-PD-2-12RV. University of Arkansas Cooperative Extension Service, Little Rock.

NRC. 2001. Nutrient Requirements of Dairy Cattle. 7th rev. ed. National Academy Press, Washington, DC.

Peters, J. B., S. Combs, B. Hoskins, J. Jarman, J. Kovar, M. Watson, A. Wolf, and N. Wolf. 2003. Recommended methods of manure analysis. \#A3769. Univ. of Wisconsin Extension, Madison, WI. http://uwlab.soils.wisc.edu/pubs/A3769.pdf.

Rowbotham, R. F., and P. L. Ruegg. 2015. Association of bedding types with management practices and indicators of milk quality on larger Wisconsin dairy farms. J. Dairy Sci. 98:7865-7885.

Rowbotham, R. F., and P. L. Ruegg. 2016a. Association of selected bedding types with incidence rates of subclinical and clinical mastitis in primiparous Holstein dairy cows. J. Dairy Sci. 99:4707-4717.

Rowbotham, R. F., and P. L. Ruegg. 2016b. Bacterial counts on teat skin and in new sand, recycled sand, and recycled manure solids used as bedding in freestalls. J. Dairy Sci. 99:6594-6608.

Schreiner, D. A., and P. L. Ruegg. 2003. Relationship between udder and leg hygiene scores and subclinical mastitis. J. Dairy Sci. 86:3460-3465.

Shook, G. E. 1993. Genetic improvement of mastitis through selection on somatic cell count. Vet. Clin. North Am. Food Anim. Pract. 9:563-581.

van Gastelen, S., B. Westerlaan, D. J. Houwers, and F. J. C. M. van Eerdenburg. 2011. A study on cow comfort and risk for lameness and mastitis in relation to different types of bedding materials. J. Dairy Sci. 94:4878-4888.

Wildman, E. E., G. M. Jones, P. E. Wagner, R. L. Boman, H. F. Troutt Jr., and T. N. Lesch. 1982. A dairy cow body condition scoring system and its relationship to selected production characteristics. J. Dairy Sci. 65:495-501.

Zdanowicz, M., J. A. Shelford, C. B. Tucker, D. M. Weary, and M. A. G. von Keyserlingk. 2004. Bacterial populations on teat ends of dairy cows housed in free stalls and bedded with either sand or sawdust. J. Dairy Sci. 87:1694-1701. 